\title{
Molecular characterization of the levansucrase gene from the endophytic sugarcane bacterium Acetobacter diazotrophicus SRT4
}

\author{
Juan Arrieta, ${ }^{1}$ Lázaro Hernández, ${ }^{1}$ Alberto Coego, ${ }^{1}$ Vivian Suárez, ${ }^{1}$ \\ Ezequiel Balmori, ${ }^{1}$ Carmen Menéndez, ${ }^{1}$ Marie-Françoise Petit-Glatron, ${ }^{2}$ \\ Régis Chambert ${ }^{2}$ and Guillermo Selman-Housein ${ }^{1}$
}

Author for correspondence: Juan Arrieta.e-mail: plantas@ingen.cigb.edu.cu

1 Center for Genetic
Engineering and
Biotechnology, Agriculture
Division, PO Box 6162,
Havana, Cuba
2 Institut Jacques Monod,
Centre National de la
Recherche Scientifique,
Université Paris 7-Denis
Diderot, Laboratoire
Génétique et Membranes,
Tour 43, 2 place Jussieu,
75251 Paris Cedex 05,
France

\begin{abstract}
The Acetobacter diazotrophicus SRT4 gene encoding levansucrase (EC 2.4.1.10) (IsdA) was isolated from a genomic library. The nucleotide sequence of a $2.3 \mathrm{~kb}$ DNA fragment sufficient for complementation of a levansucrase-deficient mutant (obtained by EMS treatment) was determined. The IsdA gene (1751 bp) coded for a polypeptide of molecular mass $64.9 \mathrm{kDa}$ with an isoelectric point of 5.2. The $\mathrm{N}$-terminal amino acid sequence of the extracellular levansucrase indicated the presence of a precursor protein with a putative signal sequence of 51 residues which is possibly cleaved in two successive steps. Expression of the IsdA gene from the lac promoter in Escherichia coli resulted in the production of a protein with levansucrase activity. The deduced amino acid sequence of the IsdA gene was $48 \%$ and $46 \%$ identical with the levansucrases from the Gram-negative bacteria Zymomonas mobilis and Erwinia amylovora, respectively, but only 28-31\% identical with levansucrases from Gram-positive bacteria. Multiple alignments of published levansucrase sequences from Gramnegative and Gram-positive bacteria revealed eight conserved motifs. A comparison of the catalytic properties and the sequence of the $A$. diazotrophicus levansucrase with those of the Bacillus subtilis levansucrase suggested that one of these motifs may be involved in the specificity of the synthesized product. Disruption of the IsdA gene in the genome of $A$.

diazotrophicus resulted in a mutant lacking both levansucrase activity and the ability to utilize sucrose as a carbon source, suggesting that levansucrase is the key enzyme in sucrose metabolism of A. diazotrophicus.
\end{abstract}

Keywords: Acetobacter diazotrophicus, levansucrase, lsd $A$ gene

\section{INTRODUCTION}

Acetobacter diazotropbicus is the only nitrogen-fixing species identified in the genus Acetobacter (Gillis et al., 1989). It is a Gram-negative bacterium and has been isolated from sucrose-rich plants including sugarcane, sweet potato, sweet sorghum and Cameroon-grass (Paula et al., 1991). A. diazotrophicus infects sugarcane roots, stems and leaves, and is mostly found in the apoplastic fluid of stem parenchyma where the sucrose content is about $12 \%(0.34 \mathrm{M})$ and the $\mathrm{pH} 5.5$ (Dong et al., 1994).

The GSDB accession number for the nucleotide sequence reported in this paper is L41732.
Under similar conditions in the free-living state, the bacterium synthesizes an extracellular levansucrase (Hernández et al., 1995). This enzyme releases fructooligosaccharides and levan, a high-molecular-mass fructosyl polymer, from sucrose. These exopolysaccharides may be a recognition signal in the micro-organism-plant interaction (James et al., 1994).

Many micro-organisms belonging to Gram-negative and Gram-positive species produce levansucrase. Comparison of the levansucrase structural genes sequenced to date shows that several short domains of the deduced polypeptide sequences are conserved (Song et al., 1993). It has not been possible to correlate the small differences observed in these motifs with differences in their catalytic 
specificities. One reason for this is that the catalytic properties of most of these enzymes are poorly characterized.

The catalytic mechanism of $A$. diazotrophicus levansucrase was recently studied in detail (Hernández et al., 1995) and compared with that of the well-characterized levansucrase produced by Bacillus subtilis. Both enzymes form a fructosyl enzyme intermediate as the first step of transfructosylation with similar kinetic parameters, but the patterns of the products released are different. Levansucrase of $A$. diazotrophicus, unlike the enzyme of $B$. subtilis, causes accumulation of large quantities of tri- and tetrasaccharides but small quantities of high-molecularmass levan. Differences in the primary structures of the two enzymes may be correlated with their different product profiles.

All known levansucrases are secreted proteins. Characterization and comparison of their intrinsic secretion signals may help elucidate differences in the mechanisms of secretion from Gram-negative and Grampositive bacteria.

Here, we report the cloning of the $A$. diazotropbicus levansucrase structural gene and the determination of its sequence.

\section{METHODS}

Bacterial strains, plasmids and media. The bacterial strains and plasmids used in this study are listed in Table 1. Escherichia coli was grown in Luria broth, supplemented with $50 \mu \mathrm{g}$ ampicillin $\mathrm{ml}^{-1}$ and $12.5 \mu \mathrm{g}$ tetracycline $\mathrm{ml}^{-1}$ as appropriate. $A$. diazotrophicus strains were grown either in LGIE medium [LGI

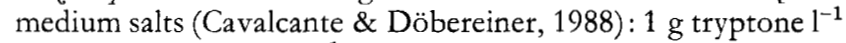
and 0.2 g yeast extract $l^{-1}$ supplemented with $5 \%(\mathrm{w} / \mathrm{v})$ sucrose and $1 \%(\mathrm{v} / \mathrm{v})$ glycerol], SB liquid medium (Coego et al., 1992) or GYC agar medium (De Ley et al., 1984): $1 \%(\mathrm{w} / \mathrm{v}$ ) yeast extract, $3 \%(\mathrm{w} / \mathrm{v})$ D-glucose, $3 \%(\mathrm{w} / \mathrm{v}) \mathrm{CaCO}_{3}$ and $2.5 \%$ (w/v) agar.

Isolation of $A$. diazotrophicus mutants deficient in levan synthesis by EMS mutagenesis. The method described by Miller (1972) was used for EMS mutagenesis, with some modifications. A. diazotropbicus strain SRT4 was grown aerobically in SB medium at $30^{\circ} \mathrm{C}$ for $48 \mathrm{~h}$. Bacteria $(1.5 \mathrm{ml}$ culture in an Eppendorf tube) were harvested by centrifugation, washed with $1.5 \mathrm{ml}$ LGI salts, resuspended in $0.5 \mathrm{ml} 2 \%(\mathrm{w} / \mathrm{v}$ ) EMS in $0.2 \mathrm{M}$ Tris/ $\mathrm{HCl}, \mathrm{pH} 7.4$, and incubated at $30^{\circ} \mathrm{C}$ for $90 \mathrm{~min}$. The treated cells were collected by centrifugation, washed with $1 \mathrm{ml} 5 \%$ (w/v) $\mathrm{NaS}_{2} \mathrm{O}_{3}$ in $0.2 \mathrm{M}$ Tris/ $\mathrm{HCl}, \mathrm{pH}$ $7 \cdot 4$, resuspended in $3 \mathrm{ml} \mathrm{SB}$ medium supplemented with $1 \%$ glycerol and grown with aeration for $16 \mathrm{~h}$ at $30^{\circ} \mathrm{C}$. The bacterial culture was plated onto LGIE medium and incubated at $30^{\circ} \mathrm{C}$. Colonies with a non-mucous phenotype were picked, grown in liquid LGIE medium and assayed for levansucrase activity. The mortality resulting from EMS treatment was $80 \%$.

Cosmid library construction. Total DNA from $A$. diazotrophicus strain SRT4 was partially digested with the restriction endonuclease Sau3AI. Fragments of $15-30 \mathrm{~kb}$ were isolated from a low-melting-temperature agarose gel and ligated to BamHIcleaved and dephosphorylated vector $\mathrm{PPW} 12$ DNA. The library was packaged into lambda phage particles using Gigapack Plus mixtures. The packaged cosmids were transferred by infection to E. coli strain S17-1 which was then plated onto LB medium supplemented with tetracycline $\left(12.5 \mu \mathrm{g} \mathrm{ml}^{-1}\right)$. The gene bank (approximately 7000 clones) was collected in $4.8 \mathrm{ml} \mathrm{LB}$ medium, and kept frozen at $-70^{\circ} \mathrm{C}$ in $20 \%$ glycerol.

Complementation experiments. The cosmid bank in E. coli S17-1 was mobilized into the $A$. diazotropbicus Lev $^{-}$mutant M21 by conjugal mating. The donor and recipient bacteria were mixed on GYC agar plates and incubated for $24 \mathrm{~h}$ at $30^{\circ} \mathrm{C}$. The mating mixture was collected and plated onto LGIE agar medium with $5 \%$ sucrose supplemented with $20 \mu \mathrm{g}$ tetracycline $\mathrm{ml}^{-1}$ for transconjugant selection and $25 \mu \mathrm{g}$ ampicillin $\mathrm{ml}^{-1}$ to counterselect $E$. coli donors. Single colonies which had recovered the mucous phenotype were picked. Plasmid DNA from four colonies was purified, used to transform E. coli strain S17-1 and again transferred by conjugation to the $A$. diazotropbicus mutant M21 to confirm that plasmids complemented the $\mathrm{Lev}^{-}$phenotype. Subfragments of the $7.8 \mathrm{~kb}$ fragment common to the recombinant cosmids p21R1 and p21R2 (Table 1) were subcloned into pUC18 and the mobilizable broad-hostrange vector $\mathrm{pRK} 293$.

Electroporation of $\boldsymbol{A}$. diazotrophicus cells. Bacteria were grown in LGIE medium ( $200 \mathrm{ml})$ with vigorous shaking at $30{ }^{\circ} \mathrm{C}$ to early exponential phase $\left(A_{600}\right.$ of $\left.0 \cdot 3-0 \cdot 4\right)$. The culture was then chilled on ice for $15 \mathrm{~min}$. Cells were harvested by centrifugation, washed twice with $100 \mathrm{ml}$ ice-cold $10 \%$ glycerol and resuspended in $2 \mathrm{ml} 10 \%$ glycerol. Aliquots of $0.15 \mathrm{ml}$ were frozen in liquid nitrogen and stored at $-70^{\circ} \mathrm{C}$. A mixture of $0.3 \mu \mathrm{g}$ plasmid DNA and $0.04 \mathrm{ml}$ cells previously thawed on ice was transferred to a chilled $2 \mathrm{~mm}$ electroporation cuvette. Electroporation was performed with a Gene Pulser Apparatus (Bio-Rad) at $9000 \mathrm{~V} \mathrm{~cm}^{-1}, 200 \Omega, 25 \mu \mathrm{F}$. The resulting time constant was $4 \cdot 0-4.8 \mathrm{~ms}$. Immediately after electroporation, $1 \mathrm{ml}$ cold LGIE medium was added to the cuvette, cells were resuspended gently, transferred to polypropylene tubes and incubated at $30^{\circ} \mathrm{C}$ for $3 \mathrm{~h}$ with slow shaking. Bacterial dilutions were plated on LGIE medium supplemented with kanamycin $\left(120 \mu \mathrm{g} \mathrm{ml}^{-1}\right)$ and incubated at $30^{\circ} \mathrm{C}$.

Purification of levansucrase from $A$. diazotrophicus culture supernatants. A. diazotrophicus SRT4 was grown to stationary phase in LGIE medium containing $2 \%$ glycerol as carbon source at $30^{\circ} \mathrm{C}$. Under these conditions, levansucrase represents more than $70 \%$ of total extracellular protein. Bacteria were removed by centrifugation. The culture supernatant was collected and concentrated fivefold using a rotatory evaporator. High-molecular-mass exopolysaccharides were precipitated by ethanol $[60 \%(\mathrm{v} / \mathrm{v})$ final concentration $]$ and centrifugation. Levansucrase remained in the supernatant fraction from which ethanol was removed using a rotatory evaporator. The enzyme solution was dialysed against $20 \mathrm{mM}$ Tris $/ \mathrm{HCl}, \mathrm{pH} 7 \cdot 5$, and passed through a DEAE-Sepharose CL-6B (fast flow) column $(2.5 \times 13 \mathrm{~cm})$ equilibrated with $20 \mathrm{mM}$ Tris $/ \mathrm{HCl}, \mathrm{pH} 7 \cdot 5$. The proteins adsorbed on the column were selectively eluted with a linear concentration gradient from 100 to $500 \mathrm{mM} \mathrm{NaCl}$. The peak fractions with levansucrase activity were pooled, dialysed against a solution of $1 \%(\mathrm{w} / \mathrm{v}) \mathrm{NH}_{4} \mathrm{HCO}_{3}, \mathrm{pH} 8.0$, and lyophilysed. The purified levansucrase gave a single band of approximately $60000 \mathrm{Da}$ following SDS-PAGE.

$\mathbf{N}$-terminal sequencing of the extracellular $\boldsymbol{A}$. diazotrophicus levansucrase. The $\mathrm{N}$-terminal sequence analysis of the purified levansucrase was performed by the Edman degradation procedure (Bauw et al., 1989) using a gas-phase sequencer (model 470A, Applied Biosystems) equipped with an on-line phenylthiohydantoin amino acid derivative analyser (model 120A). 
Table 1. Bacterial strains and plasmids used in this study

\begin{tabular}{|c|c|c|}
\hline $\begin{array}{l}\text { Bacterial strain } \\
\text { or plasmid }\end{array}$ & Genotype or description & $\begin{array}{l}\text { Reference or } \\
\text { source }\end{array}$ \\
\hline \multicolumn{3}{|l|}{ E. coli } \\
\hline XL1-Blue & $\begin{array}{l}\text { thi rec } A 1 \text { end } A 1 \text { gyr } A 96\left(\mathrm{Nal}^{\mathrm{r}}\right) \text { bsd } \mathrm{R} 17\left(\mathrm{r}_{\mathrm{k}}^{-} \mathrm{m}_{\mathrm{k}}^{+}\right) \text {supE44 relA1 } \\
\Delta(\text { lac-pro } A B)\left[\mathrm{F}^{\prime} \text { pro } A B \text { lac } \mathrm{I}^{\mathrm{a}} Z \mathrm{DM} 15 \mathrm{Tn} 10\right]\end{array}$ & Stratagene \\
\hline S17-1 & thi pro bsdR $\operatorname{rec} A[\mathrm{RP} 4-2(\mathrm{Tc}:: \mathrm{Mu})(\mathrm{Km}:: \operatorname{Tn} 7)]$ & Simon et al. (1983) \\
\hline \multicolumn{3}{|l|}{ A. diazotrophicus } \\
\hline SRT4 & Wild-type, Lev ${ }^{+}$ & Coego et al. (1992) \\
\hline M21 & EMS mutant, $\mathrm{Lev}^{-}$ & This study \\
\hline $\mathrm{AD} 1 ; \mathrm{AD} 2$ & SRT4 lsd $A:: n p t I I-b l e$ cassette, $\mathrm{Lev}^{-}$ & This study \\
\hline $\mathrm{AD} 3 ; \mathrm{AD} 4$ & SRT4 lsd $A:: \mathrm{pALS} 40, \mathrm{Lev}^{+}$ & This study \\
\hline \multicolumn{3}{|l|}{ Plasmids } \\
\hline pPW12 & $\begin{array}{l}\text { Derivative of cosmid pLAFR1 with EcoRI-BamHI-EcoRI linker, } \\
\mathrm{Tc}^{r}\end{array}$ & $*$ \\
\hline pRK293 & IncP-mobilizable cloning vector, $\mathrm{Tc}^{\mathrm{r}} \mathrm{Km}^{\mathrm{r}}$ & Ditta et al. (1985) \\
\hline pUC4-KIXX & $\begin{array}{l}\text { pUC4K-based plasmid carrying the } \operatorname{Tn} 5 \mathrm{Km}^{\mathrm{r}} \text { and } \mathrm{Bl}^{\mathrm{r}} \text { resistance } \\
\text { genes, } \mathrm{Ap}^{\mathrm{r}} \mathrm{Km}^{\mathrm{r}} \mathrm{Bl}^{\mathrm{r}}\end{array}$ & Pharmacia \\
\hline pUC18; pUC19 & Cloning vector, $\mathrm{Ap}^{\mathrm{r}}$ & Pharmacia \\
\hline $\mathrm{p} 21 \mathrm{R} 1$ & $\begin{array}{l}\mathrm{pPW} 12 \text { with a } 20 \mathrm{~kb} \text { insert of } A \text {. diazotrophicus DNA containing } \\
\text { the } l s d A \text { gene, } \mathrm{Tc}^{\mathrm{r}}\end{array}$ & This study \\
\hline $\mathrm{p} 21 \mathrm{R} 2$ & $\begin{array}{l}\mathrm{pPW} 12 \text { with a } 24 \mathrm{~kb} \text { insert of } A \text {. diazotrophicus DNA containing } \\
\text { the } l s d A \text { gene, } \mathrm{Tc}^{r}\end{array}$ & This study \\
\hline pALS5 & $\begin{array}{l}5 \cdot 2 \mathrm{~kb} \text { SalI-EcoRI fragment from } \mathrm{p} 21 \mathrm{R} 1 \text { inserted into pUC19, } \\
\mathrm{Ap}^{\mathrm{r}}\end{array}$ & This study \\
\hline pALS10 & $\begin{array}{l}2 \cdot 3 \mathrm{~kb} B g / \mathrm{II} \text { fragment from } \mathrm{p}^{21 \mathrm{R} 2} \text { inserted in the BamHI site of } \\
\mathrm{pUC18}, \mathrm{Ap}^{\mathrm{r}}\end{array}$ & This study \\
\hline pALS11 & $\begin{array}{l}\text { pUC18 carrying a } 2 \cdot 8 \mathrm{~kb} S m a \mathrm{I} \text { fragment from } \mathrm{p} 21 \mathrm{R} 2 \text {, plac-lsd } A \\
\text { fusion, } \mathrm{Ap}^{\mathrm{r}}\end{array}$ & This study \\
\hline pALS15 & $\begin{array}{l}\text { pALS10 HindIII-linearized and inserted in the HindIII site of } \\
\text { pRK293, Ap }{ }^{r} T^{r}\end{array}$ & This study \\
\hline pALS40 & $\begin{array}{l}\text { pALS5 with the } n p t I I-b l e \text { cassette from pUC4-KIXX inserted in } \\
\text { the BamHI site of } l s d A, \mathrm{Ap}^{\mathrm{r}} \mathrm{Km}^{\mathrm{r}} \mathrm{Bl}^{\mathrm{r}}\end{array}$ & This study \\
\hline
\end{tabular}

*AFRC-IPSR Nitrogen Fixation Laboratory, University of Sussex, Brighton, East Sussex, UK.

The initial sequencing yield was $1.4 \%$, indicating strong blocking of the $\mathrm{N}$-terminus.

DNA sequencing. Sequencing was performed using pALS10 (Table 1) as the template by the dideoxy chain-termination method (Sanger et al., 1977) with a Sequenase sequencing kit. The whole sequence of the levansucrase gene was determined on each strand using direct and reverse primers and the primer walking procedure with 16-mer oligonucleotides as primers. The nucleotide sequences were compiled and analysed by the BioSOS program package (Bringas et al., 1992). FASTA (Pearson \& Lipman, 1988) and BLAST (Altshul et al., 1990) programs were used for similarity searches in the SwissProt and EMBL databases, and the Waling option in the molecular modelling program WHAT IF (Vriend, 1990) used to obtain multiple sequence alignments. Protein secondary structure in levansucrases were predicted by the PHD program (Rost $e t$ al., 1995).

Expression of the $A$. diazotrophicus levansucrase gene in $\boldsymbol{E}$. coli. A $2.8 \mathrm{~kb} S m a \mathrm{I}$ DNA fragment (from nucleotide 369 , corresponding to the position five amino acids downstream from the cleavage site of the processed levansucrase, Fig. 2) was ligated into the $S \mathrm{maI}$ site (in-frame in the $5^{\prime}$ region of lac $Z^{\prime}$ ) of pUC18 under the control of the lac promoter. The resulting plasmid, named pALS11, was used to transform E. coli strain XL1-Blue. After induction by IPTG $(0.1 \mathrm{mM})$, total proteins were assayed for levansucrase activity and analysed by Western blotting.

\section{Other techniques}

DNA manipulations. Standard methods were used for recombinant DNA procedures (Sambrook et al., 1989).

Levansucrase assays. Levansucrase enzyme assays both in solution and on SDS-polyacrylamide gels were as reported previously (Hernández et al., 1995).

Antibody preparation. Rabbit polyclonal antibodies were raised against extracellular levansucrase purified by preparative SDSPAGE from culture supernatants of $A$. diazotropbicus SRT4.

Western blotting. Protein electrophoresis was carried out on a SDS-polyacrylamide gel $(12 \%$, w/v, acrylamide). After electrophoresis, proteins were transferred onto a nitrocellulose membrane, probed with polyclonal antibodies against the $A$. diazotrophicus levansucrase, and binding detected using ${ }^{125} \mathrm{I}-$ labelled Protein A.

Enzymes and chemicals. Restriction enzymes, T4 DNA ligase and oligonucleotides were purchased from Heber Biotec and 
radiochemicals from Amersham. EMS was from Koch-Light, sequencing kits from US Biochemicals and Gigapack Plus packaging mixtures from Stratagene.

\section{RESULTS}

\section{Isolation and characterization of A. diazotrophicus EMS-induced mutants deficient in levan synthesis}

A. diazotrophicus strain SRT4 forms mucous colonies surrounded by levan when grown on sucrose-containing media due to the action of an extracellular levansucrase. Nine non-mucous colonies were isolated after EMS treatment at a frequency of $2.5 \times 10^{-4}$. There were two classes of mutants according to their phenotype. Class I mutants (two colonies) did not express detectable levansucrase activity either in culture supernatants or in sonicated cell pellets. These mutants were totally complemented by the introduction of the wild-type levansucrase gene $(l s d A)$ indicating that mutations in the structural gene for the enzyme were likely. Class II mutants (seven colonies) were defective in levansucrase secretion but retained the intracellular activity of the wildtype strain. These mutants remained unable to secrete levansucrase even after introducing the structural $l s d A$ gene.

A class I mutant, named M21, was used as host for the genetic complementation experiments to isolate the levansucrase gene from an $A$. diazotropbicus SRT4 genomic library.

\section{Cloning of an A. diazotrophicus genomic fragment encoding levansucrase}

A genomic library of $A$. diazotropbicus was constructed in the broad-host-range cosmid pPW12 $\left(\right.$ mob $\left.^{+}\right)$in E. coli S17$1\left(\mathrm{Tra}^{+}\right)$. The library was transferred by conjugal mating into the levan-deficient mutant M21. Two recombinant cosmids, p21R1 and p21R2, sharing a common $7.8 \mathrm{~kb}$ region, were found to restore the $\mathrm{Lev}^{+}$phenotype to the mutant M21. The restriction map of the common $7.8 \mathrm{~kb}$ region was determined (Fig. 1a). In subcloning experiments, a $2.3 \mathrm{~kb} B g / \mathrm{II}$ fragment was obtained in pALS15, sufficient for complementation of the mutant M21.

The presence of a single $l s d A$ locus on the $A$. diazotrophicus genome was deduced from Southern hybridization analysis (Fig. 1b).

\section{DNA sequence analysis of the complementing region}

The sequence of the $2.3 \mathrm{~kb}$ fragment was determined on both strands (Fig. 2). It contained two ORFs in opposite orientations. ORFI has two putative translation initiation codons preceded by potential ribosome-binding sites: ATG (nt 201-203) and ATG (nt 325-327). It ends at two adjacent stop codons (nt 1954-1959). There is a potential rho-independent transcription terminator $[\Delta G-24 \cdot 1 \mathrm{kcal}$ $\left.\mathrm{mol}^{-1}\left(-100 \cdot 8 \mathrm{~kJ} \mathrm{~mol}^{-1}\right)\right] 9 \mathrm{nt}$ downstream from the last stop codon. The hairpin comprises a stem of twelve base pairs and a loop of four unpaired bases, the stem-loop

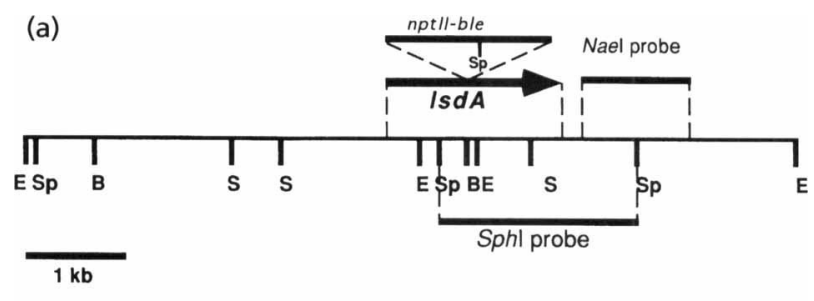

(b)

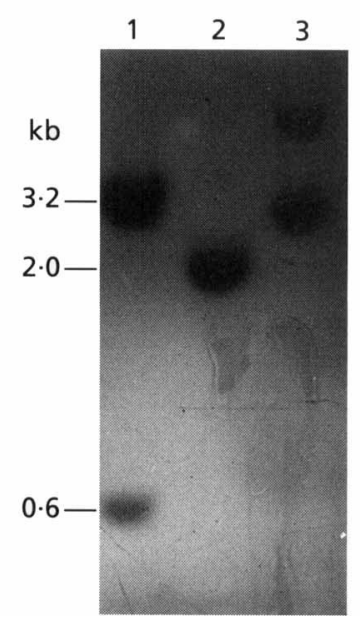

Fig. 1. (a) Restriction map of the $7.8 \mathrm{~kb}$ fragment common to p21R1 and p21R2 cosmids. E, S, Sp and B represent EcoR1, Sall, Sphl and BamHI restriction sites, respectively. The IsdA ORF is represented by the arrow. The insertion of the nptll-ble cassette in the BamHI site of the IsdA gene is shown. (b) Southern hybridization analysis of $A$. diazotrophicus SRT4. Total DNA was digested with EcoRI (lane 1), Sphl (lane 2) or Sall (lane 3) and probed with a ${ }^{32} \mathrm{P}$-labelled $2 \mathrm{~kb}$ Sphl fragment containing the IsdA gene from $A$. diazotrophicus. Hybridization was done in $0.5 \mathrm{M}$ sodium phosphate buffer, $\mathrm{pH} 7.2$, containing $7 \%(\mathrm{w} / \mathrm{v})$ SDS, $1 \%(\mathrm{w} / \mathrm{v}) \mathrm{BSA}$ at $65^{\circ} \mathrm{C}$. The nitrocellulose sheet was then washed in $0.1 \times$ SSC containing $0.1 \%$ SDS at $65^{\circ} \mathrm{C}$.

structure is followed by four consecutive $U$ residues. ORFII overlaps completely with ORFI in the opposite direction, extending beyond the end of the $B g / \mathrm{II}$ fragment in pALS10.

\section{Identification of ORFI as the A. diazotrophicus levansucrase gene}

The expression of ORFI in E. coli under the lac promoter of pUC18 resulted in a polypeptide with levansucrase activity detected by the enzymic synthesis of levan after fractionation of a cell extract on a SDS-polyacrylamide gel. The protein exhibited the expected molecular mass $(60 \mathrm{kDa})$ and was recognized by polyclonal antibodies raised against the extracellular levansucrase (Fig. 3). The polypeptide encoded by ORFI consisted of 584 amino acids from the first ATG codon. Residues $52-61$ of the predicted amino acid sequenc were identical to the $\mathrm{N}$ terminal sequence G-G-P-L-F-P-G-R-S-L of the secreted levansucrase determined by Edman degradation. The putative processed protein had a calculated molecular mass of $58 \cdot 1 \mathrm{kDa}$ and an isoelectric point of $5 \cdot 2$, which is 


\begin{abstract}
GATCTGGTAITGTGCGGAGCCGCCATGATTCCGCCTTAAATCTTTCATTAAAATAAATT TंGACATCCGTAÄATTCCCCGTGATCTTCTGC

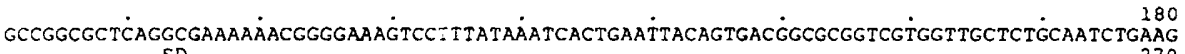
AGTTTCCTTCAGGAGGATGGAATGGCGCATGTAGGCCGAAAAAGTAGCCACGGTTAATATGGGCGTTGGCCGGGTTCCTGCCTCATGGTGCTG

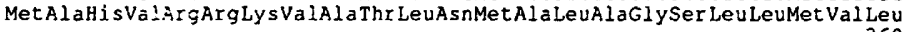
GGCGCGCAAB̈GTGCGCTGGĆGCAAGGGAATTTCAGCCGGCAGGAAGCCGCGCGCATGGCGCACCGTCCGGGTGTGATGCCंTCGTGGCGGC

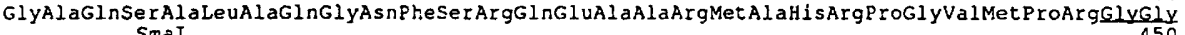
CCGCTCTTCCCCCGGGCGGTCGGCTGGCCGGGGTGCCGGGCTTCCCGCTGCCCAAGCATTCATACGCAGCAGGGGTATGACCCGCAGTCGGAC

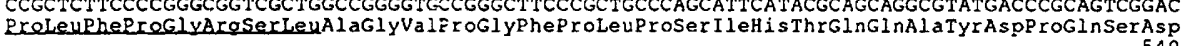

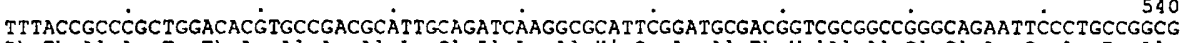

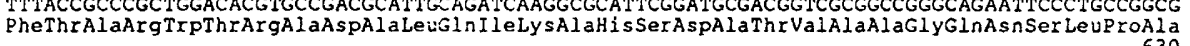

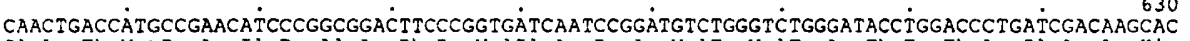

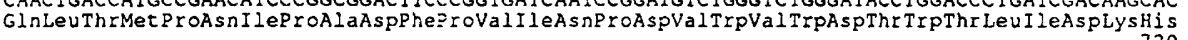

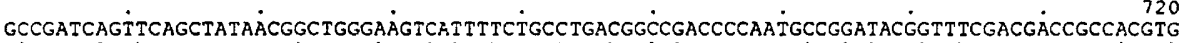
AlaAspGInPheSerTyrAsnGIYTrPGIUVaII lePheCy LeUThrAlaAspR IOAsnAlaGlyTyrGIyPheAspAspArgHisVaI CATGCCCGCÁTCGGCTTCTTCTATCGTCGĊGCGSGTATTĆCCGCCAGCCǴGCGGCCGGTǴAATGGCGGCTGGACCTATGGCGGCCATCTC

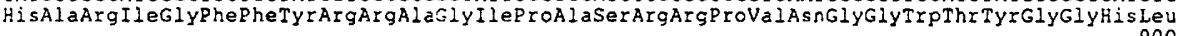

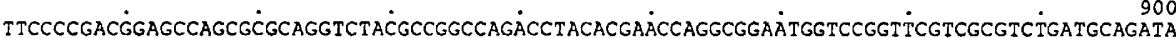
PheP rOA SPG IYALASerAlaG InVaLTY CATGGCAATÁCCGTATCGGT́TTTCTATACĆGACGTGGCGTTCAACCGTGÄCGCAACGCCAACAACATCÄCCCCGCCGCÄGGCCATCATC HisGlyAsnThrValSerValPheTyrThrAspValAlaPheAsnArgAspAlaAsnAlaAsnAsnI leThrProproglnAlaI leI le ACCCAGACCĆTGGGGCGGATCCACGCCGACंTTCAACCATǴTCTGGTTCAĊGGGCTTCACĆGCCCACACGĆCGCTGCTGCAGCCCGACGGC ThrGInThrLeUGlyArgIleHisAlaAspheAsnHisValTrpPheThrGlyPheThrAlaHisThrP roleuLeuGinProAspGly GTGCTGTATCAGAACGGTGCGGAGAACGAATTCTTCAATTTCCGCGATCCGTTCACCTTCंGAGGACCCGÄAGCATCCCGGCGTGAACTAC

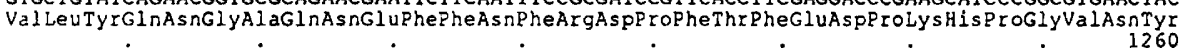
ATGGTGTTCGAAGGGCAATACCCGCGGGCCAGCGTGGCGTCG்CCAACTGCACCGAGGCCGA TंCTGGGCTTCC̈GCCCGAACGÁTCCCAATGCG

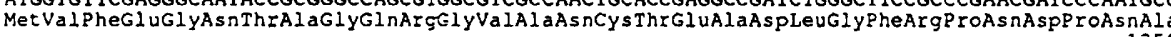

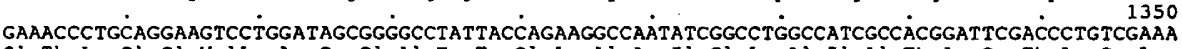
GluThr LeuGInGIUValLevAspSerGlyAlaTyrTyrGInLysAlaAsnI leGlyLeuAlaI leAlaThrAspSerThrLeuSerLys TGGAAGTTCCंTGTCGCCGCTGATTTCGGCCAACTGCGTCÄATGACCAGACCGAACGGCCGCAGGTGTACCंTCCATAACGGAAAATACTAT

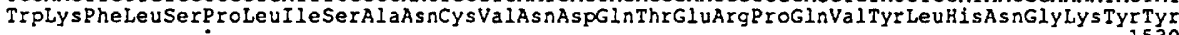
ATCTTCACCATCAGCCACCG்ACGACCTTCGGCGCCGGTǴTCGATGGACCGGACGGCGTĆTACGGCTTCGITGGGTGACGGCATCCGCAGT IlePheThrIleSerHisArgThrThrPheAlaA aGlyValAspGlyProAspGlyValTyrGlyPheValGlyAspGlyIleArgSer GACTTCCAGĆCGATGAACTÁTGGCAGCGGĆCTGACGATGG̈GCAATCCGACCGACCTCAACACGGCGGCAGGCACGGATTTCGATCCCAGC AspPheGlnProMetAsnTyrGlySerGlyLeuThrMetGlyAsnProThrAspLeuAsnThrAlaAlaGlyThrAspPheAspProSer CCGGACCAGAACCCGCGGGCCTTCCAGTCCTATTCGCACTACGTCATGCCGGGGGGACIGGTTGAATCGTTCATCGACACGGTGGAAAAC ProAspGInAsnProArgAlaPheGInSerTyrSerHisTyrValMetProGlyGlyLeuValGluSerPheI leAspThrValGluAsn

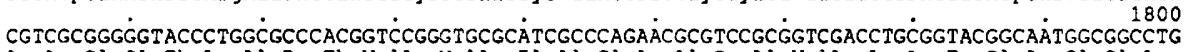

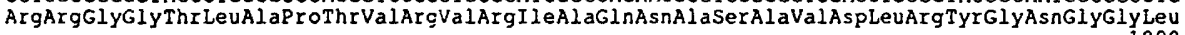
GGCGGCTATGGGGATATTCC̈GGCCAACCGĆCGGGACGTGÄACATCGCCGG̈CTTCATCCAGGATCTGTTCG̈GCCAGCCCAC̈GTCGGGTCTG

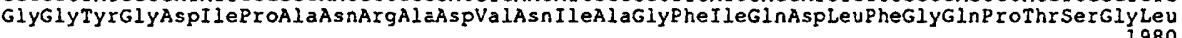
GCGGCGCAGǴCGTCCACCAAंCAATGCCCAGGTGCTGGCGCAGGTTCGCCÄATTCCTGAACCAGTAATGACGGGGTTCGACCAGCCCGCCC AlaAlaglnAlaSerThrAsnAsnAlaglnValleuAlaglnValargGinPheLeuAsnGIn * * ALAALGLINAL OSETThIASNASNAL 2009
\end{abstract}

Fig. 2. Nucleotide and deduced amino acid sequences of the $A$. diazotrophicus IsdA gene. The potential ribosomebinding site (SD) is in italics. The $\mathrm{N}$-terminal amino acid sequence of the extracellular levansucrase determined by Edman degradation is underlined. The inverted repeat sequence downstream of the two stop codons which may serve as transcriptional terminator is indicated by arrows.

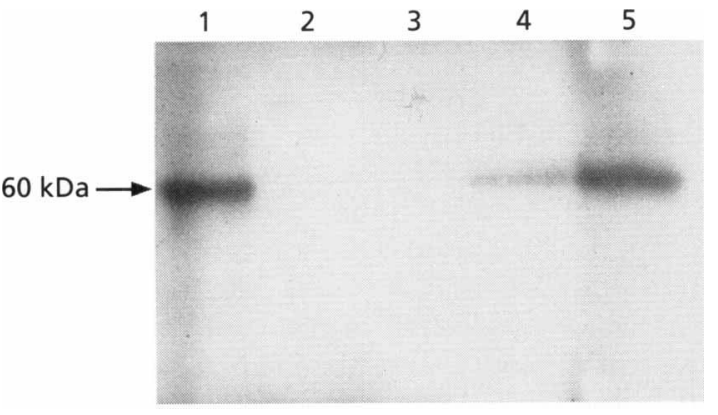

Fig. 3. Western blot analysis of IsdA gene expression in $E$. coli. Lanes: 1, extracellular levansucrase purified from $A$. diazotrophicus SRT4; 2, E. coli XL1-Blue(pUC18); 3, E. coli XL1Blue(pUC18) (IPTG-induced); 4, E. coli XL1-Blue(pUCLS28); 5, E. coli XL1-Blue(pUCLS28) (IPTG-induced). in good agreement with data obtained from purified extracellular levansucrase (Hernández et al., 1995). Similarity searches in the SwissProt and EMBL databases revealed the highest scores for bacterial levansucrases, particularly from Gram-negative bacteria. Thus, we conclude that ORFI (hereafter referred to as the $l s d A$ gene) encodes the $A$. diazotropbicus levansucrase.

\section{Codon usage of the IsdA gene}

The overall $\mathrm{G}+\mathrm{C}$ content of the $l s d A$ gene was $63 \mathrm{~mol} \%$, in agreement with the high $\mathrm{G}+\mathrm{C}$ percentage of $A$. diazotrophicus genomic DNA (De Ley et al., 1984). The frequency of adenine and thymine in the third positions of the codons was only $18 \%$. Eleven codons were not found in the $A$. diazotropbicus $l s d A$ gene, eight of these codons 


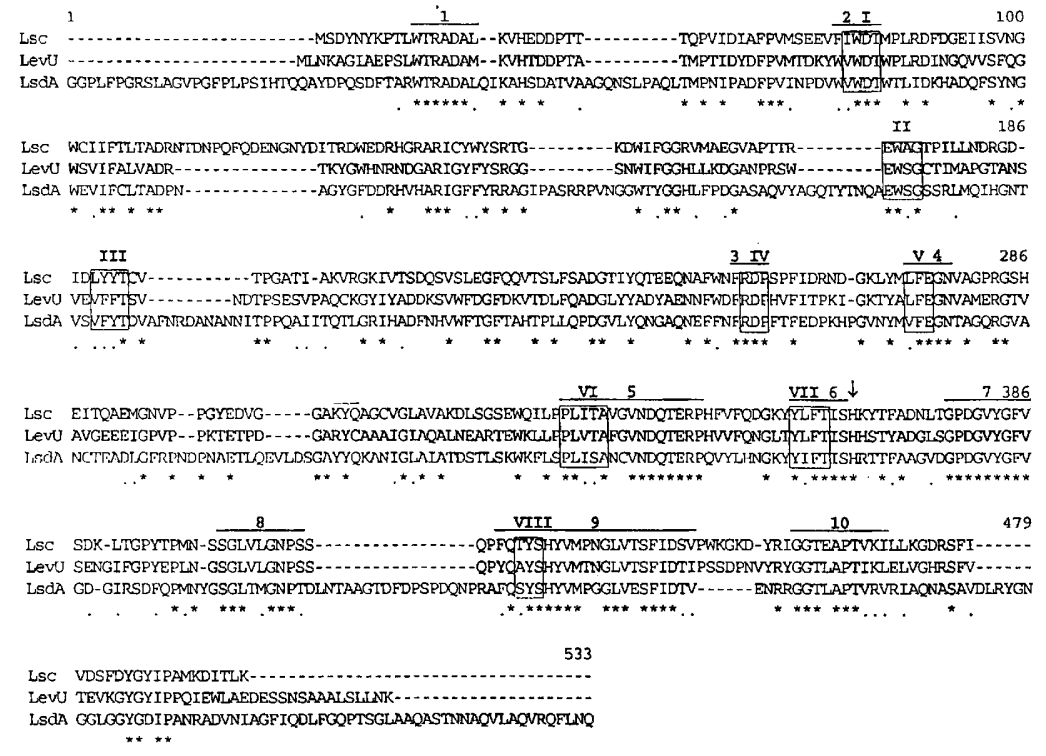

Fig. 4. Multiple sequence alignment of levansucrases from Gram-negative bacteria: Lsc, Erwinia amylovora; LevU, Zymomonas mobilis; LsdA, Acetobacter diazotrophicus. Asterisks indicate identity and dots indicate conservative changes (S-T-A, L-V-I-M, K-R, D$\mathrm{E}, \mathrm{Q}-\mathrm{N}, \mathrm{F}-\mathrm{Y}-\mathrm{W}$ ). Regions that are conserved in the three levansucrases are overlined and numbered from 1 to 10 . Regions conserved in all levansucrases, including those from Gram-positive bacteria, are boxed and numbered from I to VII. A vertical arrow indicates the $\mathrm{His}$ residue in the position corresponding to the Arg-331 of B. subtilis levansucrase (see Discussion). Numbering refers to the processed form of the $A$. diazotrophicus levansucrase.
(TTA, CTA, TCT, TCA, AGA, AGG, ACT and CCA) are also rare in sequenced genes from various other Acetobacter species (Fukaya et al., 1990; Saxena et al., 1990; Tamaki et al., 1991).

\section{Similarity with other bacterial levansucrases}

An alignment of the deduced amino acid sequence of $A$. diazotrophicus levansucrase with those published from other bacterial levansucrases showed a high degree of identity with enzymes produced by the Gram-negative bacteria Zymomonas mobilis (48\%) (Song et al., 1993) and Erwinia amylovora (46\%) (Geier \& Geider, 1993). The most similar regions were detected predominantly in the C-terminal part of the proteins (Fig. 4).

The sequence is only $28-31 \%$ identical to levansucrases from the Gram-positive bacteria Streptococcus mutans (31\%) (Shiroza \& Kuramitsu, 1988), B. subtilis (28\%) (Steinmetz et al., 1985) and Bacillus amyloliquefaciens (28\%) (Tang et al., 1990).

In the B. subtilis enzyme, substitution of Arg-331 in the conserved motif VII by His or Lys substantially affected the pattern of the products synthesized (Chambert \& Petit-Glatron, 1991). There is a His residue at the corresponding position in the $A$. diazotrophicus levansucrase (arrow in Fig.4). Furthermore, the B. subtilis levansucrase variant Arg-331 to His has catalytic properties similar to those of the $A$. diazotrophicus enzyme. Both enzymes synthesize small amounts of high-molecularmass levan but accumulate oligofructosides (Chambert \& Petit-Glatron, 1991; Hernández et al., 1995). This is further evidence for an involvement of this region in levansucrase specificity.

\section{Insertional inactivation of the IsdA gene in $A$. diazotrophicus}

To investigate the role of LsdA in sucrose metabolism, the $l s d A$ gene in the bacterial genome was inactivated by disruption.

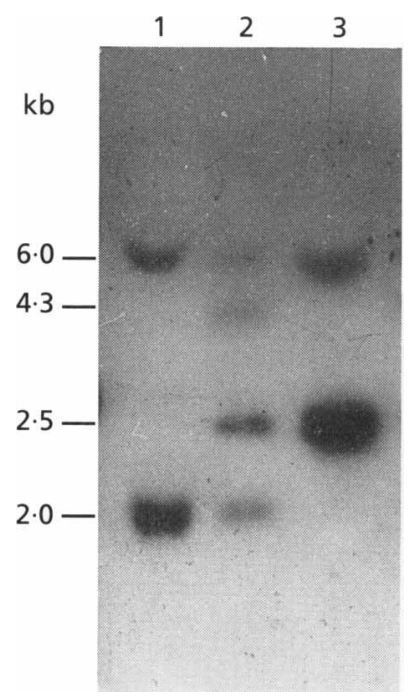

Fig. 5. Southern blot analysis of insertionally disrupted $1 s d A$ mutants. Genomic DNA was cleaved with Sphl. Hybridization was done, under the same conditions as in Fig. 1(b), with a ${ }^{32} \mathrm{P}$ labelled $1.1 \mathrm{~kb}$ Nael fragment downstream of the $1 \mathrm{sd} A$ gene from A. diazotrophicus. Lanes: 1, SRT4; 2, AD3 (or AD4); 3 , $A D 1$ (or $A D 2$ ).

The kanamycin-bleomycin resistance cassette ( $n p t I I-b l e$, $1.6 \mathrm{~kb}$ ) from pUC4-KIXX was inserted into pALS5 at the $B a m H I$ site of the $l s d A$ coding region (Fig. 1a) to create plasmid pALS40. This plasmid was introduced by electroporation into $A$. diazotrophicus SRT4. Transformants were selected on LGIE plates containing kanamycin $\left(120 \mu \mathrm{g} \mathrm{ml}^{-1}\right)$ and were obtained at a frequency of $5 \times 10^{-4}$.

No transformants were obtained after electroporation with pUC4-KIXX, suggesting that the kanamycin-resistant transformants were the result of homologous recombination of pALS40 into the SRT4 genome. About two-thirds of the transformants had the non-mucous 
colony morphology characteristic of levan-defective mutants, whereas one-third of the colonies displayed the mucous phenotype of the wild-type strain SRT4. Two colonies from each phenotype were chosen for further examination. The integration of the $n p t I I-b l e$ cassette in the transformants was confirmed by Southern hybridization. In the non-mucous mutants, designated $\mathrm{AD} 1$ and $\mathrm{AD} 2$, the $l s d A$ gene was disrupted, indicating double crossover events (Fig. 5, lane 3). The mucous transformants, named AD3 and AD4, arose from singlecrossover events: both the pALS40 sequence and an unaltered copy of the $l s d A$ gene were present in the bacterial genome (Fig. 5, lane 2).

The lsdA::nptII-ble $A$. diazotrophicus non-mucous mutants AD1 and AD2 were tested for levansucrase activity and sucrose utilization in LGIE liquid medium containing sucrose as the sole carbon source. The mutants did not display levansucrase activity, and were unable to hydrolyse sucrose and consequently to use it as a carbon source for growth. These results suggest that LsdA may be responsible for all sucrose utilization by $A$. diazotrophicus.

\section{DISCUSSION}

To understand the genetic mechanism of host specificity in the symbiotic association between $A$. diazotrophicus and sucrose-rich plants, it would be useful to identify the bacterial genes involved in sucrose metabolism. Recently, we reported the isolation and enzymic properties of the $A$. diazotrophicus extracellular levansucrase. Here, we describe cloning the structural gene for the enzyme by complementation assays. To our knowledge, the levansucrase gene $\left(l_{s} d A\right)$ is the first sequenced gene encoding an $A$. diazotropbicus enzyme.

Translation of the $l s d A$ gene may start either at position 201 or 325 . However, only the $\mathrm{N}$-terminal sequence of the deduced protein starting at the ATG at position 201 shows the characteristic features of a signal peptide (von Heijne, 1986). Assuming that the upstream ATG is the initiation codon, the $l s d A$ gene encodes a precursor protein of 584 amino acids. According to von Heijne (1986), the putative signal peptidase cleavage site may be located between Ala-30 and Gln-31. However, protein sequencing of the native extracellular levansucrase suggests that the $\mathrm{N}$-terminal 51 amino acids are removed. Transmembrane and periplasmic proteins in other species of the genus Acetobacter have long signal peptides (Inoue et al., 1989; Tamaki et al., 1991). However, the 51 residue sequence is longer than most signal peptides from other Gram-negative bacteria including Acetobacter. It is thus possible that there are two successive proteolytic cleavages during the secretion process of the enzyme, the first cleavage releasing a proprotein-like enzyme.

A long ORF completely overlaps the $l s d A$ gene in the opposite orientation. Similarly, a long ORF has been found on the antisense strand of the gene encoding the $72 \mathrm{kDa}$ subunit of the alcohol dehydrogenase from Acetobacter aceti (Inoue et al., 1989). An involvement of the antisense-strand ORF in the levansucrase gene expression of $A$. diazotrophicus cannot be ruled out.

There is a strong preference for cytosine and guanine in the third position of the $l s d A$ gene codons, consistent with the high $\mathrm{G}+\mathrm{C}$ content of Acetobacter genomic DNA (De Ley et al., 1984). The codon usage in the $A$. diazotrophicus $l s d A$ gene is similar to that of other nonregulatory genes from other species of the genus Acetobacter (Fukaya et al., 1990; Saxena et al., 1990).

No sequences similar to $E$. coli promoter consensus sequences were identified upstream from the $l s d A$ gene, suggesting that the $l s d A$ gene was not expressed from its own promoter in E. coli. Similarly, the promoters of genes from other Acetobacter species do not function in E. coli (Fukaya et al., 1990; Saxena et al., 1990).

Extensive sequence similarities were found among levansucrases from Gram-negative bacteria. There were conserved regions throughout the sequences although the greatest identity was in the C-terminal part of the proteins. The N-terminal conserved region W(T/S)RADA(L/M) was very close to the initiation codon of the $Z$. mobilis and E. amylovora levansucrases. This supports the assumption that the two enzymes are not cleaved during the transport process and are subject to a signal-peptideindependent export mechanism (Song et al., 1993; Geier \& Geider, 1993). This conserved region, which is absent from Gram-positive levansucrases, was also found in the $\mathrm{N}$-terminal amino acid sequence of levansucrase from the Gram-negative bacterium Pseudomonas syringae pv. phaseolicola (Hettwer et al., 1995). It may thus be characteristic of Gram-negative levansucrases.

In the regions of greatest similarity (Fig. 4), there are two particular differences between the $A$. diazotrophicus levansucrase and those of other Gram-negative bacteria: the substitution of Gly by Cys interrupting conserved region 5 , and the presence of a 16 amino acid segment between domains 8 and 9, resulting in a longer predicted loop in the protein secondary structure.

Bacterial levansucrases catalyse transfructosylation from sucrose to water (hydrolase activity) or to levan (polymerase activity). Each type of activity may be separately modulated in the B. subtilis levansucrase by the single replacement of the Arg-331 (Chambert \& PetitGlatron, 1991). The substitution of this Arg with a His residue caused a reduction in the ratio of polymerase to hydrolase activity in the B. subtilis enzyme. Its capacity to polymerize fructose is apparently blocked at the first step, i.e. the formation of the trisaccharide kestose, whereas sucrose hydrolysis activity remains unchanged. In the Gram-negative levansucrases, a His occupies the position corresponding to Arg-331. This amino acid substitution may be a simple explanation for the relatively high levels of 1-kestose and low levels of high-molecular-mass levan synthesized by the natural levansucrase of $A$. diazotrophicus (Hernández et al., 1995) and Z. mobilis (Crittendon $\&$ Doelle, 1993). The role of this residue could be further studied by site-directed mutagenesis. However, other domains highly conserved in the C-terminal part of the 
Gram-negative enzymes may contribute to the production and accumulation of fructo-oligosaccharides.

In this study, gene disruption was found to be a feasible method for selectively mutating defined loci in $A$. diazotropbicus for functional analysis of the corresponding gene product. We constructed $A$. diazotropbicus mutants in which the $l s d A$ gene was specifically disrupted. These mutants totally lost their levansucrase activity and their potential to utilize sucrose as a carbon source (Alvarez \& Martinez-Drets, 1995). At the usual concentration of sucrose used in the culture medium (Hernández et al., 1995), levansucrase acts more as a sucrose hydrolase than as a fructan polymerase. Therefore, we conclude that Lsd A is the key enzyme in the sucrose metabolism of $A$. diazotropbicus SRT4 and is possibly involved in bacterial colonization of sucrose-rich plants.

\section{ACKNOWLEDGEMENTS}

We thank A. Edelman for help with the English text. This work was partially financed by a grant (BIO2-CT93-0400) from the BIOTECH programme of the Commission of the European Communities

\section{REFERENCES}

Altshul, S. F., Gish, W., Miller, W., Myers, E. W. \& Lipman, D. J. (1990). Basic local alignment search tool. J Mol Biol 215, $403-410$.

Alvarez, B. \& Martinez-Drets, G. (1995). Metabolic characterization of Acetobacter diazotropbicus. Can J Microbiol 41, 918-924.

Bauw, G., Van Damme, J., Puype, M., Vandekerckhove, J., Gesser, B., Ratz, G. P., Lauridsen, J. B. \& Celis, J. E. (1989). Proteinelectroblotting and -microsequencing strategies in generating protein data bases from two-dimensional gels. Proc Natl Acad Sci US A 86, 7701-7705.

Bringas, R., Ricardo, R., Fernández de Cossío, J., Ochagavía, M. E., Suárez, A. \& Rodríguez, R. (1992). BioSOS: A program package for the analysis of biological sequences in the microcomputer. Biotecnol Apl 9, 180-185.

Cavalcante, V. A. \& Döbereiner, J. (1988). A new acid-tolerant nitrogen-fixation bacterium associated with sugarcane. Plant Soil 108, 23-31.

Chambert, R. \& Petit-Glatron, M. F. (1991). Polymerase and hydrolase activities of Bacillus subtilis levansucrase can be separately modulated by site directed-mutagenesis. Biochem J 279, 35- 41 .

Coego, A., Ramirez, R., Menéndez, C., Arrieta, J., Hernández, L., Suarez, V., Selman, G. \& Pérez, S. (1992). Isolation and characterization of nitrogen-fixing bacteria associated to sugarcane. Rev Latinoam Microbiol 34, 189-195.

Crittenden, R. G. \& Doelle, H. W. (1993). Structural identification of oligosaccharides produced by Zymomonas mobilis levansucrase. Biotechnol Lett 15, 1055-1060.

De Ley, J., Swings, J. \& Gossel, F. (1984). Genus I. Acetobacter Beijerinck. $1898,215^{A L}$. In Bergey's Manual of Systematic Bacteriology, vol. 1, pp. 268 274. Edited by N. R. Krieg \& J. G. Holt. Baltimore: Williams \& Wilkins.

Ditta, G., Schmidhauser, T., Yakobson, E., Lu, P., Liang, X. W., Finlay, D. R., Guiney, D. \& Helinski, D. R. (1985). Plasmids related to the broad host range vector, pRK290, useful for gene cloning and for monitoring gene expression. Plasmid 13, 149-153.

Dong, Z. M., Canny, M. J., McCully, M. E., Roboredo, M. R., Cabadilla, C. F., Ortega, E. \& Rodes, R. (1994). A nitrogen-fixing endophyte of sugarcane stems - a new role for the apoplast. Plant Physiol 105, 1139-1147.

Fukaya, M., Takemura, H., Okumura, H., Kawamura, Y., Horinouchi, S. \& Beppu, T. (1990). Cloning of genes responsible for acetic acid resistance in Acetobacter aceti. J Bacteriol 172, 2096-2104.

Geier, G. \& Geider, K. (1993). Characterization and influence on virulence of the levansucrase gene from the fireblight pathogen Erwinia amylovora. Physiol Mol Plant Patbol 42, 387-404.

Gillis, M., Kersters, K., Hoste, B., Janssens, D., Kroppenstedt, R. M., Stephan, M. P., Teixeira, K. R. S., Döbereiner, J. \& Deley, J. (1989). Acetobacter diazotrophicus sp. nov., a nitrogen-fixing acetic acid bacterium associated with sugarcane. Int J Syst Bacteriol 39 , 361-364.

von Heijne, G. (1986). A new method for predicting signal sequence cleavage sites. Nucleic Acids Res 14, 46834690.

Hernández, L., Arrieta, J., Menendez, C., Vazquez, R., Coego, A., Suarez, V., Selman, G., Petit-Glatron, M. F. \& Chambert, R. (1995). Isolation and enzymatic properties of levansucrase secreted by Acetobacter diazotrophicus SRT4, a bacterium associated with sugar cane. Biochem J 309, 113-118.

Hettwer, U., Gross, M. \& Rudolph, K. (1995). Purification and characterization of an extracellular levansucrase from Pseudomonas syringae pv. phaseolicola. J Bacteriol 177, 2834-2839.

Inoue, T., Sunagawa, M., Mori, A., Imai, C., Fukuda, M., Tagaki, M. \& Yano, K. (1989). Cloning and sequencing of the gene encoding the 72 kilodalton dehydrogenase subunit of alcohol dehydrogenase from Acetobacter aceti. J Bacteriol 171, 3115-3122.

James, E. K., Reis, V. M., Olivares, F. L., Baldani, J. I. \& Dőbereiner, J. (1994). Infection of sugar cane by the nitrogen-fixing bacterium Acetobacter diazotrophicus. J Exp Bot 45, 757-766.

Miller, J. H. (1972). Experiments in Molecular Genetics. Cold Spring Harbor, NY: Cold Spring Harbor Laboratory.

Paula, M. A., Reis, V. M. \& Dobbereiner, J. (1991). Interactions of Glomus clarum with Acetobacter diazotropbicus in infection of sweet potato (Ipomea batatas), sugarcane (Saccharum spp) and sweet sorghum (Sorghum vulgare). Biol Fertil Soils 11, 111-115.

Pearson, W. R. \& Lipman, D. J. (1988). Improved tools for biological sequence comparison. Proc Natl Acad Sci USA 85, 2444-2448.

Rost, B., Casadio, R., Fariselli, P. \& Sander, C. (1995). Transmembrane helices predicted at $95 \%$ accuracy. Protein Sci $\mathbf{4}$, $521-533$

Sambrook, J., Fritsch, E. F. \& Maniatis, T. (1989). Molecular Cloning: a Laboratory Manual, 2nd edn. Cold Spring Harbor, NY: Cold Spring Harbor Laboratory.

Sanger, F., Nicklen, S. \& Coulson, A. R. (1977). DNA sequencing with chain-terminating inhibitors. Proc Natl Acad Sci USA 74, 5463-5467.

Saxena, I. M., Lin, F. C. \& Brown, R. M. (1990). Cloning and sequencing of the cellulose synthase catalytic subunit gene of Acetobacter xylinum. Plant Mol Biol 15, 673-683.

Shiroza, T. \& Kuramitsu, H. K. (1988). Sequence analysis of the Streptococcus mutans fructosyltransferase gene and flanking regions. $J$ Bacteriol 170, 810-816.

Simon, R., Priefer, U. \& Puhler, A. (1983). Vector plasmids for in vivo and in vitro manipulations of Gram-negative bacteria. In 
Molecular Genetics of the Bacteria-Plant Interaction, pp. 98-106. Edited by A. Pühler. Berlin: Springer-Verlag.

Song, K. B., Joo, H. K. \& Rhee, S. K. (1993). Nucleotide sequence of levansucrase gene (levU) of Zymomonas mobilis ZM1 (ATCC10988). Biochim Biophys Acta 1173, 320-324.

Steinmetz, M., Le Coq, D., Aymerich, S., Gonzy-Tréboul, G. \& Gay, P. (1985). The DNA sequence of the gene for the secreted Bacillus subtilis enzyme levansucrase and its genetic control site. Mol Gen Genet 200, 220-228.

Tamaki, T., Fukaya, M., Takemura, H., Tayama, K., Okumura, H., Kawamura, Y., Nishiyama, M., Horinouchi, S. \& Beppu, T. (1991).
Cloning and sequencing of the gene cluster encoding two subunits of membrane-bound alcohol dehydrogenase from Acetobacter polyoxogenes. Biochim Biophys Acta 1088, 292-300.

Tang, L. B., Lenstra, R., Borchert, T. V. \& Nagarajan, V. (1990). Isolation and characterization of levansucrase-encoding gene from Bacillus amyloliquefaciens. Gene 96, 89-93.

Vriend, G. (1990). WHAT IF : a molecular modeling and drug design program. J Mol Graph 8, 52-56.

Received 23 October 1995; revised 3 January 1996; accepted 8 January 1996. 